\title{
Keynes, family allowances, and Keynesian economic policy
}

\author{
Steven Pressman* \\ Department of Economics and Finance, Monmouth University, West Long Branch, NJ, USA
}

\begin{abstract}
This paper provides a short history of family allowances and documents the fact that Keynes supported family allowances as early as the 1920s, continuing through the 1930s and early 1940s. Keynes saw this policy as a way to help households raise their children and also as a way to increase consumption without reducing business investment. The paper goes on to argue that a policy of family allowances is consistent with Keynesian economics. Finally, the paper uses the Luxembourg Income Study to estimate the impact of family allowances on child poverty in several developed nations and estimates the poverty-reducing impact of several possible family allowance programs for the US.
\end{abstract}

Keywords: Keynes, family allowances, anti-poverty policy, child poverty

JEL codes: $B 31, D 3, H 4, I 3$

\section{INTRODUCTION}

Family or child allowances are regular payments made to families on behalf of their children. They can be made either by the government or by private firms. Usually payments are universal. They are made without regard to family income; all households with children below a certain age qualify for them; the income level of the family does not matter. Their purpose is to assist families with children by raising their income, and by so doing help families support their young dependents. Also, these payments do not depend on work effort by the household head; in this respect, family allowances differ from other forms of assistance to families with children, such as the Earned Income Tax Credit in the US.

Another way to think about family allowances is that it is a policy that keeps families from being penalized because they have a large number of children and many mouths to feed. It is well known that poverty rates rise with the number of children in the household. According to the US Census Bureau (2008), for 2007 the official poverty rate for households without children was just 4.6 percent. In contrast, households with one child had a poverty rate of 12.5 percent and households with two children had a poverty rate of 16.9 percent. My own calculations for the United States, using the Luxembourg Income Study (LIS) and a relative definition of poverty, give similar results. The poverty rate for US households with just one child in 2010 was 18.8 percent and 20.4 percent for households with two children; but the poverty rate jumps to 32.9 percent for households with three children and to 46.3 percent for households with four children.

* The author thanks two anonymous referees for their comments on an earlier version of this paper. The usual disclaimer applies. 
Keynes advocated family allowances as a way to help households raise their children. Rather well known are two long articles supporting family allowances as a way to help finance the war effort. These were published in The Times in November 1939, and then expanded into a small book, How to Pay for the War, in 1940 (Keynes 1940 [1972]). But, as this paper shows, contrary to the claims of Toye (2000) and others, Keynes supported family allowances well before the late 1930s. The paper then argues that Keynesians should support family allowances as a means of mitigating poverty. To provide some empirical support for this, it examines the poverty-reducing impact of family allowances in developed nations and some possible family allowance plans for the US.

We begin with some historical background.

\section{A HISTORY OF FAMILY ALLOWANCES}

Glass (1940, p. 86) claims that the ancient forerunners of family allowances were the pro-natalist clauses in the Babylonian Code of Hammurabi and three laws passed by Roman Emperor Augustus between $18 \mathrm{BC}$ and $9 \mathrm{AD}$ that encouraged marriage and raising children. Another important forerunner, according to Glass (ibid., p. 92) was the French Edict of 1666, which sought to encourage population growth in France by various means. To take just one example of how this was done, fathers with at least ten legitimate children were exempt from paying all taxes, as long as none of the children was a priest or a nun.

The Speenhamland system, introduced in England in 1795, is usually regarded as the first family allowance program in the modern world. Speenhamland was a response to the end of feudalism in England. Because landowners no longer accepted responsibility for their serfs, there was a sharp rise in malnutrition, in poverty, and in begging on the streets. As Block and Somers (2005, p. 16) describe it: 'Speenhamland refers to a town in Berkshire County, England, where the country squires decreed in May 1795 that the poor should be entitled to a specific quantity of assistance depending upon the price of bread and the size of the family.' To deal with the problem of poverty, the town provided more assistance to larger families and thereby tried to put a floor under family living standards.

In The Great Transformation, Karl Polanyi describes the system in considerable detail. Like Keynes, Polanyi worried about social dislocation from a market economy and how the government could help protect society from some of the harsh effects of competitive capitalism such as high unemployment and great income inequality. By providing a secure source of income to workers, Speenhamland mitigated some of the harsh effects of capitalism. Yet, also like Keynes (see later), Polanyi (1944, p. 81) worried about whether such assistance would lower the wages of workers; with Speenhamland, firms would need to pay their workers less, as the government (or the local parish) would provide the income necessary for sustenance and reproduction. In fact, Polanyi speculated that, in a real market economy, Speenhamland would have driven the wage rate down to zero and destroyed the labor market.

What we regard today as family allowances, however, began in France. Around 1870, a private firm, Val-des-Bois Works, began making a special payment to their workers who had children to support. From a social perspective, this was regarded as a fringe benefit to workers with larger families. But from the point of view of the firm, the plan was seen as a means to keep wage costs down in an era of high inflation and great pressure for higher wages in France (Haanes-Olsen 1972, p. 18). Thus, 
the main goal in establishing this program was not to help families with children as much as it was to control firm payroll. Rather than increasing the wages of all workers, family allowances let firms increase the wages of just some workers (that is, those with many children) and raise the incomes of households with children to subsistence levels.

Another path to family allowances arose from special birth bonuses that firms in France began offering their workers in 1890 . This is actually closer to contemporary family leave policies or maternity benefits; but the bonuses soon became family allowances. In 1910, French firms began extending payments beyond the birth of the child, making them annually to households with children (Vadakin 1968, p. 45).

Regardless of how they developed historically, it soon became clear that a system of payments for children made by individual firms generated several problems. Those firms that did not pay allowances gained a competitive advantage over their rivals, while firms that did pay their workers child allowances faced higher production costs. In addition, employers became reluctant to hire people with large families or those who were likely to have large families, thus discriminating against young workers and those with large families.

The initial solution to these problems arose at the industry level. Employer associations began to require that all firms contribute to a child allowance fund based on the number of their employees. The fund then made payments to individual households based on the number of children in the household. Firms could no longer gain a competitive advantage in the industry by not paying child allowances, since every firm had to make contributions to the industry fund. The tendency for firms to discriminate against workers with large families was reduced for a similar reason: employers were required to contribute to the fund, regardless of the number of children supported by their employees.

Austria can lay claim to the first employer system of family allowances; it was set up by druggists throughout the country in 1908 (Douglas 1925, p. 119). But France was really at the forefront here. The first industry-level program in France began in May 1918 (ibid., p. 54); by 1924, France had 120 such employer associations (Vadakin 1968, pp. 46-47).

Still, prisoner's dilemma types of problems arose with the family allowance systems run by employer associations. Industries providing family allowances were at a competitive disadvantage relative to those industries lacking such a program. In particular, newer industries tended to not have an association and they benefited; conversely, the established industries in the nation that were providing family allowances incurred additional costs per worker. A further problem was that younger workers and workers with large families naturally were attracted to industries with a family allowance program. New industries had difficulty attracting young workers. All this put pressure on the industry-wide family allowance system. And since younger workers with lots of children were attracted to industries paying family allowances, it also put pressure on industry associations to increase their assessments on firms. Any such assessment, of course, would generate even bigger competitive disadvantages for the industry. The solution slowly became obvious after years of experience with employer associations: nations needed a system in which all industries would have to pay family allowances to their workers.

This requires that the government establish a national family allowance program and oversee this system. A first step in this direction was taken by the Netherlands in 1912, when it granted family allowances to postal employees. It soon extended family allowances to teachers, and then in 1920 to all civil servants (Douglas 1925, p. 129). But a full national family allowance program did not develop until after World War I, with France and Belgium taking the lead. Following the war, many European countries faced inflationary pressures. Real wages were falling. Using the model of the Val-des-Bois 
Works, firms looked at family allowances as an alternative to paying higher wages to all workers. In an attempt to control labor costs, they focused on giving wage increases based on need (that is, family size) rather than providing across-the-board pay increases. Generally, payments were made monthly to the mother of the child (Vadakin 1968, p. 47).

Another force pushing for family allowance programs at the national level after World War I was concern about population growth. France was worried about their low birthrate and the consequences of this if they found themselves in another war with Germany. Family allowances became a way to increase the birthrate in France so it would keep up with, or exceed, the birthrate in Germany. Germany, of course, was worried about France, and responded by launching its own family allowance program in 1935 - for the express purpose of increasing the birthrate in Germany (Haanes-Olsen 1972, p. 18).

In August 1930, Belgium became the first country to provide a national system of family allowances. France followed suit in March 1932 (Vadakin 1968, pp. 51-52). One by one, countries throughout the world followed the lead of Belgium and France, including most less-developed nations. When Japan introduced a family allowance system in 1972 (Kirkpatrick 1972), the US became the only major industrial nation without such a policy.

\section{KEYNES AND FAMILY ALLOWANCES}

Keynes was an early advocate of family allowances. He knew of this policy through several different avenues and supported it many times.

First, Keynes certainly was aware of the work of Eleanor Rathbone, a tireless advocate for family allowances, and he supported her efforts to help large families with children. Rathbone championed many causes throughout her life - the Spanish Civil War, the rights of colored women in the British colonies, Czech refugees, anti-Nazism, and housing reform. She had been involved in the woman's suffrage movement, and she saw family allowances as an extension of the fight for economic justice for all women (Stocks 1949, pp. 115-118). Her iconoclastic and idiosyncratic views on the political and social issues of the day probably appealed to Keynes.

In 1917, Rathbone founded the Family Endowment Committee, which became the Family Endowment Society in 1938. She became a member of Parliament from 1929 to 1946, in an attempt to influence policy-making. Rathbone and her followers also wrote newspaper articles, attended political meetings, and lobbied Parliament in support of family allowances (Macnicol 1980, pp. 26-27).

Rathbone began by supporting separation allowances. These were payments made by the British government during World War I to wives and children of men serving in the British army. The payments were made based on family size, making them a forerunner of family allowances. An article by Rathbone on this topic was published by Keynes in the Economic Journal. In that article Rathbone (1917, p. 68) also argued for 'the continuation of something resembling the present system of separation allowances' in the interests of justice. She felt that for ethical reasons the government should help families with more mouths to feed.

Even more influential were a couple of books Rathbone (1924 [1947]; 1940) wrote advocating a policy of family allowances for Britain, and arguing that these payments would value women's work as caretakers. They explained how family allowances could pull large families out of poverty, and made a case that family allowances be made part of economic and social policy in the UK. 
Rathbone's 1924 book was reviewed, rather favorably, in the Economic Journal while Keynes was its editor. Phillips (1925, p. 94) called it 'a contribution of enduring importance to one of the major issues of our time.' In addition to Rathbone's 1917 paper, numerous papers on family allowances appeared in the Economic Journal during the 1920s (Campbell 1927; Heimann 1923; MacGregor 1926; Richardson 1924), including several that described family allowance programs outside the UK. One such article (MacGregor 1926) was selected by Keynes to be the lead article for the year. Many other pieces appearing in the Economic Journal during the 1920s and early 1930s discussed family allowances as part of the article and analysed their impact on things like wages, birth rates, poverty and industrial production (Davison 1930; Grier 1925; MacGregor 1933; Vlasto 1926).

By contemporary standards, one might not be able to conclude that Keynes supported family allowances just because he was publishing favorable book reviews and articles in the Economic Journal. But Keynes was not your ordinary journal editor. He frequently published his own work in the journal. Moreover, as Moggridge (1990) notes, Keynes used referees sparingly; indeed, when he first assumed the post as editor in 1912 he did not use referees at all (Moggridge 1992, pp. 208-209). When he did send papers out for review, he would frequently tell his referees what he thought about the paper he sent them, and he often included the draft of an acceptance or rejection letter. Going a bit further, Aslanbeigui and Oakes (2007) contend that Keynes used the Economic Journal for his own political purposes - to recruit disciples and allies, and actively manage the definition and dissemination of knowledge in economics. Keynes also frequently solicited articles from others. What he solicited and what he published concerned topics of interest to him and supported positions he agreed with and that he wanted to promote. From this perspective, Keynes was clearly interested in family allowance proposals in the 1920s, if not before; and it seems that he used the Economic Journal to give this idea a good deal of publicity and support.

Second, family allowances were first introduced in the UK in the 1920s and were being discussed seriously in the UK throughout that decade. In the early 1920s Prime Minister Lloyd George and his cabinet were concerned about the consequences of high unemployment. To deal with this problem, he established a cabinet committee to make recommendations about how to lower unemployment and mitigate its negative consequences for Britain. One result was the 1921 Unemployed Workers' Dependents' Act, which established a dependent allowance on a temporary basis for 6 months. In March of 1922 it was decided to continue the allowance and in February 1923 the cabinet decided to make it permanent (Macinol 1980, p. 108).

Mainly due to the efforts of Rathbone, support grew for a family allowance program in the UK that everyone would be eligible for - not just the children of unemployed workers. As Macnicol (ibid., p. 9) notes, by 1924, 'the discussion of family endowment in Britain had already manifested itself in as many as five different forms: apart from the newly-formed Family Endowment Society ... there were the State Bonus Plan, Beatrice Webb's equal wage and child endowment proposals, Seebohm Rowntree's $[1901 ; 1918]$ interest in a minimum wage plus family allowances, and a continuing discussion of motherhood endowment ...'?

Third, family allowances are consistent with the revolutionary economic theory Keynes was working on during the late 1920s and early 1930s. At this time, Keynes had already come to recognize the importance of effective demand in generating economic growth and employment, and was working on providing the theoretical foundations for his policy proposals. 
Part of the problem was great income inequality. The poor received too little income and could not spend a lot; the rich received too much income to spend. The standard view at the time was that the rich would save and that this money would thereby flow into new investment. Keynes, however, saw that investment decisions depended on animal spirits or psychological factors, and that inequality would reduce spending, profits, business expectations, and investment. The trick was how to generate more consumption spending without generating either inflation or great disincentives due to high taxes. Family allowances were one solution to this problem.

'The Question of High Wages,' published in 1930, is the first place Keynes advocated family allowances in print. It is a work that anticipates some of the policies that Keynes advanced at the end of The General Theory (1936 [1964]). In this remarkable paper, Keynes argued for higher wages in the UK in order to increase effective demand at the beginning of the depression. However, he noted that there were some problems with using this policy in a global economy. In particular, British exports would be priced out of the global market and imports would become cheap. In addition, higher wages would make businesses less profitable and so would reduce business investment. Keynes (1930 [1981], p. 12) was opposed to this: 'In short, we must not starve the goose that lays the golden eggs before we have discovered how to replace her. We must tax her eggs instead.' By this he meant taxing business profits and using the tax revenues to support the incomes of the working classes. He advocated social insurance, pensions, and 'useful expenditures by the state on health, recreation, and education, and the facilities for travel' (ibid., p. 14), an anticipation of his call for a 'socialization of investment' in The General Theory. Then he moved on to support family allowances: 'In this case I believe that the trade union movement is actively hostile on the express ground that it fears such allowances would be what I wish them to be, namely, an alternative to higher wages. It would be much better that a man with heavy family burdens to support should receive assistance out of taxation, which is thrown on profits generally, than that an attempt should be made to raise wages paid by his employer to a disproportionate level' (Keynes 1930 [1981], p. 14).

Finally, Keynes learned about family allowances, and came to support this policy proposal, through his long association with William Beveridge. After World War I, the two collaborated on an historical publishing project (Toye 2000, p. 174). Both men attended the Liberal Party Summer Schools in the early 1920s, which sought to provide progressive policy solutions to the key issues of the day. Beveridge was one of its founders, and Keynes spoke at one of the first summer schools, in August 1922.

Rathbone convinced Beveridge to support family allowances in the early 1920s. Her book converted Beveridge, who wanted to prevent further declines in fertility in the UK and thought that family allowances would help in this regard. Also, he thought it would help hold down domestic wages and make goods produced in the UK more competitive in the world economy (Toye 2000, p. 178). Beveridge wrote a positive review of Rathbone's book The Disinherited Family for the journal Weekly Westminster (Macnicol 1980, pp. 29-31) and then was made President of the Family Endowment Society.

Beveridge served on the Royal Commission on the Coal Industry (also known as the Samuel Commission) from 1925 to 1926 . The commission argued for family allowances as a means of keeping wages down and ensuring that the British coal industry remained competitive in world markets. Its report to the British government argued that family allowances would reduce absenteeism among single men in the coal mines because with lower wages (due to the tax necessary to support family allowances), they would have to work more (Macnicol 1980, pp. 33-34). In October 1927, Beveridge organized 
a conference at the London School of Economics on the subject, which then became a book: Six Aspects of Family Allowances (Family Allowance Society 1927).

In the early 1940s, Beveridge headed up his own government commission. The famous Beveridge Report (Beveridge 1942) advocated a program of family allowances in the UK. It made family allowances part of a comprehensive social safety net.

At this time Keynes was working for the Treasury, and was responsible for keeping the British budget deficit within manageable proportions. The Beveridge Report, in advocating more government programs and benefits, would of course have consequences for the

British budget. Beveridge struck a deal with Keynes regarding his plan. Keynes agreed to support the plan, including the provision for family allowances, as long as the cost to the Treasury was kept to $£ 100$ million a year for the first 5 years. After that, Keynes thought that rising Treasury revenues would be able to cover the costs of the plan (Beveridge 1953, p. 309). To achieve this, Beveridge suggested there should be no family allowances paid for the first child in each family; only subsequent children would be eligible. Beveridge felt this was justified because existing wages could support a family with one child, but not a family with more than one child.

On June 15, 1945 a bill was passed by Parliament and the first family allowances were paid in the UK on August 6, 1946. They were paid to women each Tuesday through the local Post Office (Fleming 1973).

\section{FAMILY ALLOWANCES AND KEYNESIAN ECONOMICS}

Besides being supported by Keynes, other Keynesian economists and post-Keynesian economists have advanced a family allowance program as a means to mitigate poverty. John Kenneth Galbraith (1964, p. 26) seemed to be supporting family allowances when he called for 'modest educational grants to families to feed and clothe children for school and to compensate for their earnings.' And Pressman (1992a, 1992b, 1993) has argued for family allowances as a means of generating greater income equality and lower poverty, without generating any of the negative consequences usually associated with income support programs.

This section argues that family allowances should appeal to Keynesian economists for a number of reasons. Four of these go to explain why Keynes himself was so favorably disposed towards this policy.

First, there is an argument based on effective demand and employment. Because income effects are more important than substitution effects, to end mass unemployment we must increase spending rather than reduce wages. The incentive for firms to hire workers is not lower wages as much as it is the likelihood of good sales and profits due to robust demand.

Family allowances are a progressive transfer. From the standpoint of Keynesian economics, progressive transfers take spending power from high-income households (who are taxed to finance some program) with a low marginal propensity to consume and give it to lower income households that have a high propensity to consume. Alternatively, family allowances can be financed by eliminating the current tax exemption for children in the US and then using the tax savings to finance a system of family allowances (Pressman 1992a). The result in both cases is a greater aggregate marginal propensity to consume, more consumption, more demand, and higher levels of employment (see Palley 2010).

This arises because family allowances redistribute income from more affluent households to those with less income. With fixed payments per child, no matter 
what the household income level, low-income households are aided proportionately more than wealthy ones. In addition, these payments must be financed somehow. In all nations this is done through general income tax revenues. Because most national tax systems are progressive in nature, tax burdens are greatest on wealthier households. Since they do redistribute income from likely savers to likely spenders, family allowances should increase effective demand - a view that receives considerable empirical support. ${ }^{1}$ In addition, as we saw above, households with large numbers of children are more likely to be poor than households with small numbers of children. They also have lower per capita incomes. Since family allowances give greater benefits to households with more children, even if funded by an equal assessment on each household, the plan overall would be progressive in its incidence.

One can even view this as the consumer spending equivalent to the balanced budget multiplier, introduced by Samuelson (1948; also see Pressman 2013, pp. 229-230), where a redistribution of income increases aggregate spending and generates greater economic growth. On the standard balanced budget multiplier, higher taxes take money away from savings, which then gets spent by the government (or given as transfers to households to spend). This has a stimulative macroeconomic effect. With family allowances paid for by eliminating tax exemptions for children, something similar occurs. Taxes go up and disposable income is reduced for those with high incomes when the child exemption is eliminated because they are in high tax brackets. This should reduce their savings; at the same time, the gains from family allowances go primarily to those with low incomes (because everyone gets a family allowance and the child tax exemption is not refundable to those who do not owe taxes). The end result will be more spending.

Second, as Keynes noted, the world is plagued by uncertainty rather than calculable risk; people must make decisions not knowing the consequences of their actions. As a result, animal spirits, habits, conventions, and other rules are used to help make decisions.

From the point of view of the household, family allowances reduce uncertainty by providing a fixed source of income to families with children. This income source is available to families in good times as well as in times of high unemployment. It also reduces uncertainty about the economic consequences of having more children. By providing additional income to households with additional children, family allowances make household living standards more secure. And like any social safety program, such as unemployment insurance and social security, this should encourage consumption by the family and stimulate demand for the whole economy. Moreover, this additional household spending reduces uncertainty for firms, which can now be more confident of future sales and will be more likely to invest. In essence, family allowances can give us positive macroeconomic outcomes due to both multiplier and accelerator effects.

Third, there is a growth argument for family allowances. Growing up in poverty has many negative long-term consequences. Among the most important ones are that it reduces human capital and slows down productivity growth.

Child development takes place in stages; childhood poverty retards development and how well one does later in life. During the very early and formative years of life, poverty is most damaging. It reduces educational attainment; it is detrimental to the physical health and intellectual development of the child; and it is detrimental to

1. See Alesina and Rodrik (1992; 1994); Brown (2004); Clarke (1995); Deininger and Squire (1998); Lundberg and Squire (2003); Perotti (1996). 
the emotional or psychological state of the child (Busby and Busby 1996, p. 70). These negative consequences continue throughout childhood, and into adolescence and adulthood. Those experiencing child poverty are more likely to bear children out of wedlock as a teenager, to experience unemployment as an adult, and to commit crimes and spend time in prison (see Scott and Pressman 2013).

By providing a secure source of income to large, low-income households, family allowances should also reduce the stress experienced by low-income households. Considerable research has found that income inequality contributes to stress for those at the bottom and the middle of the income distribution (Marmot 2004; Wilkinson 1994; 1996; 2000). Stress, in turn, leads to problems with one's immune system, cardiovascular system, and glucose metabolism, and it can destroy brain cells involved in memory. Stress triggers 'fight or flight' responses - chemical reactions in the body that were designed for emergency situations where an individual had to fight or flee. These responses helped save the lives of our ancestors, as well as other animals, during times of immediate threat. But with repeated stress, these chemicals remain in the bloodstream, disrupt normal body functions, and increase the probability of health problems (Sapolsky 1998). There is also some evidence that once the body experiences stress, the brain develops pathways that tend to get replicated through time by making us look for stressful situations, finding them, and by reacting in inappropriate ways that lead to long-term harm (Kishiyama et al. 2008).

Children are responsible for future economic growth and productivity growth. Because they reduce child poverty, child allowances should improve living standards for children and thus future economic growth.

Fourth and finally, the standard economic notion of rationality is frequently used against government policies such as family allowances. The usual argument is that families know best how to raise their children and parents can best maximize the utility of their children. To do so, they make decisions about how much to work and to earn, about child rearing and about the best way to provide education for their children. On this perspective, government programs distort incentives and thereby reduce utility and well-being. Samuelson (1956) first pointed out that demand functions for a multi-person household can be rational only under a very restrictive set of assumptions that are not likely to be true in the real world (for example, identical utility functions for all members of the household). To deal with this objection, Gary Becker $(1974 ; 1981)$ introduced the notion of the altruistic parent who would take the interests of other family members (even rotten kids) into account, an idea that garnered a great deal of criticism (Bergstrom 1989; Bruce and Waldman 1990; Lindbeck and Weibull 1988).

But there are problems with this argument that go beyond the question of whether rational parents can be altruistic towards their rotten kids and whether evolution favors such preferences. These are problems with the economic notion of rationality itself. Consider the classic prisoner's dilemma. Given the logic of this situation, economic rationality says that the only appropriate decision for each prisoner is to defect or confess. Both thus serve short terms in prison. This outcome is also a Pareto Optimal outcome, one that neither player can improve upon, as, if either prisoner fails to confess, it is likely that he will get a large prison term and the other person will go free. But this situation is something we can improve on. We noted this problem earlier when discussing the problem of one firm or industry providing family allowance benefits to its workers (but not others).

The good news for the human species (given that the prisoner's dilemma is also at the heart of the nuclear arms race) is that people tend to cooperate when faced with situations like the prisoner's dilemma. This is true even in single-play prisoner's dilemma experiments, where people have no reason to cooperate in the hope of enticing their opponent to 
cooperate in the future (Frank 1988, pp. 140ff; Ostrom et al. 1992). Evolutionary game theory (Axelrod 1984; 1997; Field 2002) attempts to explain how and why this is the case. It argues that cooperators will tend to survive because mutual cooperation is better than mutual defection, the only viable alternative. Among cooperators, norms or values will develop, be reinforced, and then passed on to future generations as a sort of social rationality.

Social rationality dictates that children are a national resource, rather than just a good providing utility to their parents. Treating children as a private good leads to problems that are like the prisoner's dilemma. Individual decisions about taking time off from work to stay at home and bond with newborns, as well as decisions regarding daycare, pre-school and other education fail to address any positive social impact from a well-adjusted and well-educated child. We are all worse off.

On the other hand, attempting to aid my children so that they have an advantage over other children benefits my children relative to others, just as my saving money benefits me relative to others who do not save. In both cases, such optimal individual behavior has negative aggregate consequences. For saving, Keynes identified a 'paradox of thrift'; a similar paradox arises when parents seek to support their own children in order to give them an edge over other children. In this case we get an arms race in which wealthy individuals over-invest in the education of their children, thereby requiring other families to spend more for their children if their children are to succeed. They become over-leveraged, buying homes that are too expensive and paying for private schooling, just so their children can keep up. At the other end of the income spectrum, because the poor cannot afford to make such private investments in their children, we under-invest in children. Everyone suffers from reduced innovation, output, and incomes in the future.

\section{THE IMPACT OF FAMILY ALLOWANCES ON POVERTY: AN INTERNATIONAL PERSPECTIVE}

This section uses the Luxembourg Income Study (LIS) to estimate the impact of family allowance programs on poverty in several developed nations throughout the world. The LIS is an international database containing extensive income as well as sociodemographic information on 46 countries and stretching over a period of 30 years. $^{2}$ LIS databases center around particular years, called 'waves.' Each wave is around 5 years apart, with Wave \#1 beginning in the early 1980s. The most recent data, Wave \#8, which are just starting to come online, center around the year 2010.

Somewhat surprisingly, there has been only one previous attempt to estimate the poverty-reducing impact of family allowances using the LIS (Cantillon and van den Bosch, 2003), despite the fact that the LIS database contains data on family allowances for many countries.

To analyse the impact of family allowances on poverty we need to start by defining poverty lines for each household. A first step involves adjusting household income to account for differences in household size. A \$24000 income will be able support a single individual in the US reasonably well. In 2012, it would have provided more than twice the poverty-level income for a single person. But for a family of five, an income of $\$ 24000$ provides each person with just $\$ 4800$ on average. Certainly, this

2. More information is available on the LIS homepage, at www.lisproject.org. The Appendix provides information on the original sources for LIS data. 
would not support the same lifestyle as $\$ 24000$ for a single individual; in fact, according to the US Census Bureau, a family of five would have been considered poor in 2012 with this income.

We can deal with differences in household size by treating the income needs of all household members identically and looking at per capita household income. But this ignores important economies of scale in living arrangements. Two people can live together better on a given sum of money than apart, and they will have a higher standard of living by doing so.

In what follows, we adjust household incomes using the OECD recommendations regarding equivalence scales for household size (Lyngstad et al. 1997). According to this standard, income requirements for each child are 50 percent of the requirements of the household head, and income needs for additional adults in the household are 70 percent of the requirements of the household head. These are actually close to the implicit household adjustments incorporated into the official US poverty lines developed by Mollie Orshansky $(1965 ; 1969)$. The Orshansky poverty lines came from surveys of food consumption and expenditures for different households. As such, they provide a good empirical foundation for using the OECD standards when adjusting income to account for household size. However, not a great deal rests on this decision. Other adjustment formulae have been suggested and tested, and empirical studies have found that this decision makes little difference to the broad results that one gets when using the LIS (Smeeding et al. 1988); obviously, the actual figures will differ with different adjustment rules.

Once we adjust household incomes based on household size, we need to define poverty lines for each household. Here we follow common practice and use a relative definition of poverty, defining households as poor if their adjusted household income falls below 0.5 of median-adjusted household income (for that country at that time). ${ }^{3}$

Using the LIS, our household income adjustments, and our relative definition of poverty, Table 1 provides estimates of poverty rates for households with children as well as estimates without family allowances. The nine countries were selected based on the availability of family allowance data in LIS and also to present a broad array of different approaches to government economic policy. In a classic work, Gosta Esping-Anderson (1990) described three different types of welfare regime. First, there is the Anglo-Saxon model, which puts emphasis on the free market. Second, there is the continental European model, which provides benefits to workers mainly through employment. Finally, there is the Nordic or Scandinavian model, where benefits are universal and regarded as a matter of right. The databases selected are the most recent for these countries available in the summer of 2013.

The first column of Table 1 shows that there is a broad range of poverty rates for households with children. The three Nordic countries have the lowest poverty rates for households with children, around 5 percent. The three continental European nations have poverty rates for households with children in the 10-13 percent range. And for the three Anglo-Saxon nations, the poverty rate for households with children exceeds 15 percent in all cases.

To compute poverty rates without family allowances, we subtract family allowance payments from household income and then recalculate the national poverty rate. This computation assumes no secondary effects on poverty rates as a result of introducing family allowances. One potentially important effect is that family allowances may lead

3. There are many good reasons for employing a relative definition of poverty, especially in cross-national studies. See Pressman (2002, pp. 20-21). 
Table 1 The impact of family allowances on poverty rates for households with children

\begin{tabular}{|c|c|c|c|c|}
\hline & 1 & 2 & 3 & 4 \\
\hline $\begin{array}{l}\text { Country and } \\
\text { year }\end{array}$ & $\begin{array}{l}\text { Poor households } \\
\text { with children as a } \\
\text { percentage of } \\
\text { households with } \\
\text { children }\end{array}$ & $\begin{array}{l}\text { Poor households } \\
\text { with children as a } \\
\text { percentage of } \\
\text { households with } \\
\text { children (after } \\
\text { subtracting child } \\
\text { allowances) }\end{array}$ & $\begin{array}{l}\text { Poverty-reducing } \\
\text { impact of family } \\
\text { allowances }\end{array}$ & $\begin{array}{l}\text { Percentage of } \\
\text { poor households } \\
\text { with children } \\
\text { removed from } \\
\text { poverty due to } \\
\text { child allowances }\end{array}$ \\
\hline Canada (2004) & $16.3 \%$ & $21.2 \%$ & $-4.9 \%$ & $23.1 \%$ \\
\hline Finland (2004) & $4.1 \%$ & $9.6 \%$ & $-5.5 \%$ & $57.3 \%$ \\
\hline France (2005) & $12.8 \%$ & $17.4 \%$ & $-4.6 \%$ & $26.4 \%$ \\
\hline $\begin{array}{r}\text { Germany } \\
(2010)\end{array}$ & $10.6 \%$ & $18.6 \%$ & $-8.0 \%$ & $43.0 \%$ \\
\hline $\begin{array}{l}\text { Luxembourg } \\
\text { (2010) }\end{array}$ & $12.8 \%$ & $24.9 \%$ & $-12.1 \%$ & $48.6 \%$ \\
\hline Norway (2004) & $4.5 \%$ & $8.4 \%$ & $-3.9 \%$ & $46.4 \%$ \\
\hline Sweden (2005) & $5.4 \%$ & $8.1 \%$ & $-2.7 \%$ & $33.3 \%$ \\
\hline UK (2010) & $18.9 \%$ & $22.7 \%$ & $-3.8 \%$ & $16.7 \%$ \\
\hline US (2010) & $23.5 \%$ & $23.5 \%$ & $0.0 \%$ & $0.0 \%$ \\
\hline $\begin{array}{l}\text { Averages } \\
\quad \text { (unweighted) }\end{array}$ & $12.1 \%$ & $17.2 \%$ & $-5.1 \%$ & $32.8 \%$ \\
\hline
\end{tabular}

Source: Author's calculations from the Luxembourg Income Study.

to an increase in birth rates - something that Keynes worried about a great deal, according to Toye (2000) - and therefore an increase in family size. Since, as we have seen, poverty rates increase with family size, ignoring this factor leads us to overestimate the poverty-reducing impact of family allowances.

Fortunately, this measurement error is not likely to be large. Several empirical studies have found that existing family allowances programs have had a very small impact on birth rates, and many government programs providing additional income for each additional child have had virtually no impact on birth rates. For example, Gauthier and Hatzius (1997) find that a rather large 25 percent increase in the value of family allowances would increase fertility by only around 0.07 children per woman. According to Ermisch (1988a; 1988b), family allowances mainly change the timing of child bearing; they do not lead to larger families. And Furstenberg (1976) and Rank (1989) find that welfare mothers did not change their reproductive behavior very much as a result of larger government payments for each child.

Furthermore, any impact of family allowances on family size will be countered by the second effect of family allowances on poverty. Since family allowances increase income equality, this should increase spending, thus spurring economic growth and employment (see footnote 1). This, in turn, will help those at the bottom of the income distribution most and tend to lower poverty rates, as typically occurs during periods of economic growth. For these reasons, ignoring secondary changes due to the introduction of family allowances probably should not lead to any significant bias or an incorrect measure of the impact of family allowances on poverty rates.

Columns 3 and 4 in Table 1 provide estimates of how effective family allowances are in reducing poverty for households with children. Column 3 subtracts the poverty rate in column 2 (which assumes that no family allowances are paid) from the actual rate in 
column 1. The difference between the two figures measures the poverty-reducing impact of family allowances in each nation, or what percentage of households gets removed from poverty due to family allowances. As column 3 shows, the average decrease in poverty for families with children is 5 percentage points. Column 4 calculates the percentage of poor households with children that get removed from poverty as a result of family allowances. On average, family allowances remove nearly one-third of poor families with children from the ranks of the poor.

What enables so many families and so many children to escape from poverty? Table 2 summarizes the family allowance benefits available in our nine countries. The table makes clear that the generosity of this program varies considerably from country to country, as well as the generosity of benefits that go to households with several children. Countries such as Finland, Germany, and Luxembourg, which provide more generous benefits and increase benefits per child as the number of children in the household rise, have family allowance programs that are more effective in reducing poverty for households with children.

Table 3 looks at child poverty rates. The impact here is greater than in Table 1 because of what was pointed out earlier in this paper: households with more children are more likely to be poor. In Table 1, each family gets counted once no matter how many children are in the family; in Table 3 each child gets counted once. Again, we subtract family allowances and recalculate poverty rates for children in column 2; and, again, column 3 shows that the poverty-reducing impact of family allowances is quite large. Child allowances reduce the percentage of children in poverty from around 22 percent to around 12 percent on average (unweighted), and more than one-third of otherwise poor children escape poverty due to family allowances. Excluding the US, which has no family allowance program, the decline in child poverty exceeds 40 percent.

\section{Table 2 Family allowance benefits}

\begin{tabular}{|c|c|}
\hline Country & Family allowances \\
\hline Canada & $\begin{array}{l}\text { Delivered through the income tax system - maximums are CA } \$ 2950 \text { for first } \\
\text { child; CA } \$ 2730 \text { for second child, and CA } \$ 2734 \text { for third and subsequent } \\
\text { children. }\end{array}$ \\
\hline Finland & $\begin{array}{l}€ 1200 \text { for one child; } € 2526 \text { for two children; } € 4098 \text { for three children; } € 5916 \\
\text { for four children; } € 2064 \text { for each subsequent child. }\end{array}$ \\
\hline France & $\begin{array}{l}€ 117.14 / \text { month for two children; } € 267.21 / \text { month for three children; } € 417.24 / \\
\text { month for four children; } € 150.08 / \text { month for each subsequent child. There is } \\
\text { also a supplement of } € 32.95 \text { for children older than } 11 \text { and } € 58.57 \text { for } \\
\text { children older than } 16 .\end{array}$ \\
\hline Germany & $€ 154$ /month for each of the first three children; $€ 179$ for each subsequent child. \\
\hline Luxembourg & $\begin{array}{l}€ 185.60 / \text { month for one child; } € 440.72 / \text { month for two children; } € 802.74 / \text { month } \\
\text { for three children; } € 1164.48 / \text { month for four children; } € 1526.40 / \text { month for } \\
\text { five children. There is also a } € 16.17 / \text { month bonus for each child aged } 6 \text { to } \\
11 \text { and } € 48.52 / \text { month for each child aged } 12 \text { and older. }\end{array}$ \\
\hline Norway & NOK 11640 for each child. \\
\hline Sweden & $\begin{array}{l}\text { SEK 1050/child each month with supplements of SEK } 100 \text { for a second child; } \\
\text { SEK } 354 \text { for a third child; SEK } 860 \text { for a fourth child and SEK } 1050 \text { for fifth } \\
\text { and subsequent children. }\end{array}$ \\
\hline UK & $£ 17 /$ week for the first child and $£ 11.40$ /week for each additional child. \\
\hline US & Not available. \\
\hline
\end{tabular}

Sources: Social Security Administration; social security programs throughout the world. 
Table 3 The impact of family allowances on child poverty rates

\begin{tabular}{lccccc}
\hline & 1 & & & 3 & \\
\cline { 2 - 3 } \cline { 5 - 6 } Country and year & $\begin{array}{c}\text { Child } \\
\text { poverty }\end{array}$ & $\begin{array}{c}\text { Child poverty } \\
\text { without family } \\
\text { allowances }\end{array}$ & $\begin{array}{c}\text { Poverty-reducing } \\
\text { impact of family } \\
\text { allowances }\end{array}$ & $\begin{array}{c}\text { Percentage of poor } \\
\text { children removed } \\
\text { from poverty due to } \\
\text { family allowances }\end{array}$ \\
\hline Canada (2004) & $13.2 \%$ & $25.0 \%$ & $-11.8 \%$ & $47.2 \%$ \\
Finland (2004) & $5.4 \%$ & $13.4 \%$ & $-8.0 \%$ & $59.7 \%$ \\
France (2005) & $24.5 \%$ & $31.6 \%$ & $-7.1 \%$ & $22.5 \%$ \\
Germany (2010) & $12.2 \%$ & $22.7 \%$ & $-10.5 \%$ & $46.3 \%$ \\
Luxembourg (2010) & $15.0 \%$ & $29.6 \%$ & $-14.6 \%$ & $49.3 \%$ \\
Norway (2004) & $5.9 \%$ & $10.8 \%$ & $-4.9 \%$ & $45.4 \%$ \\
Sweden (2005) & $6.6 \%$ & $10.8 \%$ & $-4.2 \%$ & $38.9 \%$ \\
UK (2010) & $21.0 \%$ & $25.4 \%$ & & $-4.4 \%$ & $17.3 \%$ \\
US (2010) & $27.8 \%$ & $27.8 \%$ & & $0.0 \%$ & $0.0 \%$ \\
Averages & $14.6 \%$ & $21.9 \%$ & $-7.3 \%$ & $36.3 \%$ \\
$\quad$ (unweighted) & & & & & \\
\hline
\end{tabular}

Source: Author's calculations from the Luxembourg Income Study.

One final point should be noted here: without child or family allowances, the US looks pretty much like the other Anglo-Saxon and continental European nations. These countries tend to have child poverty rates of between 25 percent and 30 percent without child allowances. In fact, the US does a little bit better than France and Luxembourg when we subtract child allowances; and its child poverty rate is not significantly higher than the child poverty rate for Canada or the UK. The big difference between the US and these countries, as Table 3 makes clear, is what happens to child poverty when we take family allowances into account and make them part of household income. Here, the US does considerably worse than all these countries, and does much worse than the three Scandinavian countries (which start with much lower child poverty for other reasons). These results support the introduction of a program of family allowances in the US and for other developed nations to consider expanding their family allowance programs.

Finally, we simulate the impact of three possible family allowance programs for the US. We first look at a $\$ 1000$ allowance made to all children aged 18 and under. This is the amount of the child allowance proposed by the National Commission on Children (1991) in the early 1990s. Then we look at a \$2000 allowance for each child, roughly the present value of this proposal. Finally, we look at a $\$ 3000$ child allowance. This is close to what child allowances would need to be in the US if they were around the same percentage of US disposable income as family allowances in the UK are a percentage of UK disposable income. Even at this level, family allowances would be rather meager. As we have seen, child poverty rates in the UK are quite high compared to other developed nations, despite this level of allowances. In addition, it should be noted that a $\$ 3000$ allowance still only provides $\$ 250$ per month per child.

These child allowances (of $\$ 1000, \$ 2000$, and $\$ 3000$, respectively) are presumed to be refundable; that is, they are paid to all households, even if the household has no tax liability for the year. In all three cases, we increase median-adjusted household income to account for the extra money received through family allowance payments and thus increase our poverty threshold. Then we recomputed national poverty rates. A $\$ 1000$ per-child allowance would reduce the poverty rate for US households with children 
only slightly, from 23.5 percent to 21.3 percent. A $\$ 2000$ allowance would reduce the poverty rate of households with children to 19.1 percent, and a $\$ 3000$ allowance would give the US a 17 percent poverty rate for households with children.

Overall, a \$1000-per-child allowance would still leave the US far behind the rest of the developed world in terms of child poverty rates. With a \$2000 allowance the US would start to look similar to the other Anglo-Saxon nations, while a \$3000 allowance would actually reduce child poverty rates in the US to the levels found in these countries.

There were nearly 74 million children in the US in 2012. A $\$ 1000$ allowance per child would thus cost a little less than $\$ 74$ billion. Costs for the more generous plans can be derived by just multiplying by the appropriate number. How can such expenditures be financed, especially in an era of very large budget deficits?

One way to fund family allowances would be through eliminating tax exemptions for children. Since the poor and near poor in the US effectively pay no taxes, this means of finance would not take money away from the poor with one hand while giving it back to them with the other hand. Poor households would be net gainers from this policy switch. Alternatively, the allowances can be partly financed by making them taxable. Since lowincome households pay no taxes, this would not hurt them; middle class and wealthy households would wind up paying some of the allowances back to the government in the form of higher taxes. Finally, we can fund these programs through general tax revenues and look at them, following Keynes, as a form of public investment. Holzer et al. (2007) calculate that childhood poverty costs the US $\$ 500$ billion per year, or nearly 4 percent of GDP. It does this through lowering productivity (and hence income), increasing crime rates, and raising health expenditures. Each of these factors contributes around onethird of the overall loss according to the authors. A family allowance program that cut child poverty by more than one-quarter in the US (close to the outcome of the $\$ 3000$ plan) would thus save more than 1 percent of US GDP, or around $\$ 170$ billion annually. This is only a bit below the cost of a $\$ 3000$ per child family allowance.

\section{SUMMARY AND CONCLUSION}

Over the years, family allowances have been criticized for promoting population growth, for increasing tax burdens because of the need to finance these benefits, and for lowering wage rates. Malthus (1798, p. 86) was the first and main opponent of aid to the poor because of its impact on population growth. Many have followed this road hewn by Malthus. The 1834 Poor Law Commission Report worried about the impact of Speenhamland wage subsidies on work effort. The Poor Law Commission Report was also the first report to express concern about the cost of the wage subsidy because of the number of people relying on it and the burden this would place on the local governments providing these benefits (Checkland and Checkland 1974, pp. 128-131). A Select Committee of the UK's House of Commons (Select Committee on Labourer's Wages 1824) was the first report claiming that wage supplements led to falling wages in the southern counties of the UK.

Above we dealt with the first two objections directly, by citing many empirical studies showing that family allowances do not increase birth rates; and we set forth a plan that would likely increase government tax receipts rather than reduce them. In addition, as Keynes (1937) himself noted, a growing population has many positive benefits for economic growth due to the need to spend more money because of family demographics. 
Several other authors (Blaug 1963; 1964; Boyer 1990; Digby 1982) have responded to the objection of the Select Committee. They argue that the wage supplement provided by Speenhamland was the result and not the cause of low wages. The last criticism receives further support from Keynesian economic theory, which predicts an increase in effective demand, employment, and wages as a result of instituting a policy of family allowances. This macroeconomic effect should counter any tendency for wages to fall because government benefits reduce what employers must pay workers. The relative strength of these two forces is an empirical issue that warrants further study.

Nonetheless, family allowances should be part of any Keynesian program to reduce poverty and increase income equality. Keynes supported family allowances for a good part of his adult life. The policy is consistent with the main tenets of Keynesian economics. And at the practical level, family allowances have the potential to substantially reduce poverty rates in the US, which at present are the highest in the developed world - in part because the US has no policy of family allowances. They are clearly effective in reducing child poverty in most developed nations and do not have the negative sorts of incentives associated with other redistributive policies. In addition, family allowances are well targeted on those who need the money the most: poor households with children.

Adopting a family allowance policy in the US would require dealing with a number of practical policy issues: the size of the allowance, whether allowances should vary with age or the number of children in a family, whether there should be a means test to receive it, whether it should be subject to taxation, and how to finance such a program. Then there is the issue of whether we should provide family allowances to older children enrolled in school or vocational training programs, as many European nations do. Also, we will need to address the problem of how allowances get increased over time. Should they be indexed to inflation and increased annually, the way that US Social Security payments are increased every year? Or should the government have to vote for periodic changes in the value of the family allowance? It is to these practical issues that we need to turn.

\section{REFERENCES}

Alesina, A. and Rodrik, D. (1992), Distribution, Political Conflict, and Economic Growth: A Simple Theory and Some Evidence, in: A. Cukierman, Z. Hercowitz, and L. Leiderman (eds), Political Economy, Growth, and Business Cycles, Cambridge, MA: MIT Press, pp. 23-50.

Alesina, A. and Rodrik, D. (1994), Distributive Policies and Economic Growth, Quarterly Journal of Economics, 109, 465-490.

Aslanbeigui, N. and Oakes, G. (2007), The Editor as Scientific Revolutionary: Keynes, The Economic Journal, and the Pigou Affair, Journal of the History of Economic Thought, 29, $15-48$.

Axelrod, R. (1984), The Evolution of Cooperation, New York: Basic Books.

Axelrod, R. (1997), The Complexity of Cooperation, Princeton, NJ: Princeton University Press.

Becker, G. (1974), A Theory of Social Interactions, Journal of Political Economy, 82, 1063-1094.

Becker, G. (1981), Treatise on the Family, Cambridge, MA: Harvard University Press.

Bergstrom, T. (1989), A Fresh Look at the Rotten Kid Theorem - and Other Household Mysteries, Journal of Political Economy, 97, 1138-1159.

Beveridge, W. (1942), Report on Social Insurance and Allied Services: The Beveridge Report, New York: Macmillan.

Beveridge, W. (1953), Power and Influence: An Autobiography, London: Hodder \& Stoughton. 
Blaug, M. (1963), The Myth of the Old Poor Law and the Making of the New, Journal of Economic History, 23, 151-184.

Blaug, M. (1964), The Poor Law Report Re-Examined, Journal of Economic History, 24, 228-245.

Block, F. and Somers, M. (2005), In the Shadow of Speenhamland: Social Policy and the Old Poor Law, in: K. Widerquist, M.A. Lewis, and S. Pressman (eds), The Ethics and Economics of the Basic Income Guarantee, Aldershot, UK: Ashgate, pp. 13-54.

Boyer, G. (1990), An Economic History of the English Poor Law 1750-1850, Cambridge, UK: Cambridge University Press.

Brown, C. (2004), Does Income Distribution Matter for Effective Demand?, Review of Political Economy, 16, 291-307.

Bruce, N. and Waldman, M. (1990), The Rotten Kid Theorem Meets the Samaritan's Dilemma, Quarterly Journal of Economics, 105, 155-165.

Busby, W. and Busby, F. (1996), Children in Poverty: The Fundamental Issue, Journal of Children and Poverty, 2, 65-91.

Campbell, R.M. (1927), Family Allowances in New Zealand, Economic Journal, 37, 369-383.

Cantillon, B., Marx, I., and van den Bosch, K. (2003), Social Policy Strategies to Combat Income Poverty of Children and Families in Europe, in: P. Krause, G. Bäcker, and W. Hanesch (eds), Combating Poverty in Europe - The German Welfare Regime in Practice, Aldershot, UK: Ashgate, pp. 317-329.

Checkland, S.G. and Checkland, O. (1974), The Poor Law Report of 1834, London: Penguin Books.

Clarke, G. (1995), More Evidence on Income Distribution and Growth, Journal of Development Economics, 47, 403-427.

Davison, R. (1930), Unemployment Relief in Germany, Economic Journal, 40, 140-146.

Deininger, K. and Squire, L. (1998), New Ways of Looking at Old Issues: Inequality and Growth, Journal of Development Economics, 57, 259-287.

Digby, A. (1982), The Poor Law in Nineteenth Century England and Wales, London: Historical Association.

Douglas, P. (1925), Wages and the Family, Chicago: University of Chicago Press.

Ermisch, J. (1988a), Econometric Analysis of Birth Rate Dynamics in Britain, Journal of Human Resources, 23, 53-76.

Ermisch, J. (1988b), Economic Influences on Birth Rate, National Institute Economic Review, November, 71-81.

Esping-Anderson, G. (1990), The Three Worlds of Welfare Economics, New York: Polity Press.

Family Allowance Society (1927), Six Aspects of Family Allowances, London: Family Allowance Society.

Field, A. (2002), Altruistically Inclined?, Ann Arbor, MI: University of Michigan Press.

Fleming, S. (1973), The Family Allowance Under Attack, Bristol, UK: Falling Wall Press.

Frank, R. (1988), Passions within Reason, New York: W.W. Norton.

Furstenberg, F. (1976), Unplanned Parenthood: The Social Consequences of Teenage Childbearing, New York: Free Press.

Galbraith, J.K. (1964), Let Us Begin: An Invitation to Action on Poverty, Harper's Magazine, March, 17-26.

Gauthier, A. and Hatzius, J. (1997), Family Benefits and Fertility: An Econometric Analysis, Population Studies, 51, 295-306.

Glass, D.V. (1940), Population Policies and Movements in Europe, London: Frank Cass \& Co.

Grier, L. (1925), The Meaning of Wages, Economic Journal, 35, 519-535.

Haanes-Olsen, L. (1972), Children's Allowances: Their Size and Structure in Five Countries, Social Security Bulletin, 35, 17-28.

Heimann, E. (1923), The Family Wage Controversy in Germany, Economic Journal, 33, 509-515.

Holzer, H., Schanzenbach, D., Duncan, G., and Ludwig, J. (2007), The Economic Costs of Poverty in the United States: Subsequent Effects of Children Growing Up in Poverty, Washington, DC: Center for American Progress.

Keynes, J.M. (1930 [1981]), The Question of High Wages, in: The Collected Writings of John Maynard Keynes, Vol. 20: Activities 1929-1931: Rethinking Employment and Unemployment Policies, London: Macmillan, pp. 2-16. 
Keynes, J.M. (1936 [1964]), The General Theory of Employment, Interest and Money, New York: Harcourt Brace \& World.

Keynes, J.M. (1937), Some Economic Consequences of a Declining Population, Eugenics Review, 29, 13-17.

Keynes, J.M. (1940 [1972]), How to Pay for the War, in: The Collected Writings of John Maynard Keynes, Vol. 9: Essays in Persuasion, London: Macmillan, pp. 367-439.

Kirkpatrick, E. (1972), Children's Allowances in Japan, Social Security Bulletin, 35, 39, 43.

Kishiyama, M., Boyce, W., Jiminez, A., Perry, L., and Knight, R. (2008), Socioeconomic Disparities Affect Prefrontal Function in Children, Journal of Cognitive Neuroscience, 21, 1106-1115.

Lindbeck, A. and Weibull, J. (1988), Altruism and Time Consistency: The Politics of Fait Accompli, Journal of Political Economy, 96, 1165-1192.

Lundberg, M. and Squire, L. (2003), The Simultaneous Evolution of Growth and Inequality, Economic Journal, 113, 326-344.

Lyngstad, J., Keilman, N., Bojer, H., and Thomsen, I. (1997), Poverty and Economic Inequality: Concepts, Measures, and Methods, in: N. Keilman, J. Lyngstad, H. Bojer, and I. Thomsen (eds), Poverty and Economic Inequality in Industrialized Western Societies, Oslo: Scandinavian University Press, pp. 3-31.

MacGregor, D.H. (1926), Family Allowances, Economic Journal, 36, 1-10.

MacGregor, D.H. (1933), Taxation of Co-operative Dividend, Economic Journal, 43, 40-55.

Macnicol, J. (1980), The Movement for Family Allowances, 1918-45: A Study in Social Policy Development, London: Heinemann.

Malthus, T.R. (1798), An Essay on the Principle of Population, as it Affects the Future Improvement of Society, London: Johnson.

Marmot, M. (2004), The Status Syndrome: How Social Standing Affects our Health and Longevity, New York: Times Books.

Moggridge, D. (1990), Keynes as Editor, in: J. Hay and D. Winch (eds), A Century of Economics: 100 Years of the Royal Economic Society and the Economic Journal, Oxford: Basil Blackwell, pp. 143-157.

Moggridge, D. (1992), Maynard Keynes: An Economist's Biography, New York and London: Routledge.

National Commission on Children (1991), Beyond Rhetoric: A New Agenda for Children and Families, New York: National Commission on Children.

Orshansky, M. (1965), Consumption, Work and Poverty, in: B.B. Seligman (ed.), Poverty as a Public Issue, New York: Free Press, pp. 52-84.

Orshansky, M. (1969), How Poverty is Measured, Monthly Labor Review, 92(2), 26-41.

Ostrom, E., Walker, J., and Gardner, R. (1992), Covenant with and without a Sword: SelfGovernment is Possible, American Political Science Review, 86, 404-417.

Palley, T. (2010), A Relative Permanent Theory of Consumption: A Synthetic Keynes-DuesenberryFriedman Model, Review of Political Economy, 22, 41-56.

Perotti, P. (1996), Growth, Income Distribution, and Democracy: What the Data Say, Journal of Economic Growth, 1, 149-188.

Phillips, H. (1925), Review of The Disinherited Family by Eleanor F. Rathbone, Economic Journal, 35, 92-96.

Polanyi, M. (1944), The Great Transformation, Boston: Beacon Press.

Pressman, S. (1992a), Child Exemptions or Child Allowances?, American Journal of Economics and Sociology, 51, 257-272.

Pressman, S. (1992b), The $\$ 1000$ Question: A Tax Credit to End Child Poverty?, Challenge, 35, 49-52.

Pressman, S. (1993), Tax Exemptions for Child Exemptions: A Poor Policy to Aid America's Children, Journal of Economic Issues, 27, 699-719.

Pressman, S. (2002), Explaining the Gender Poverty Gap in Developed and Transitional Economies, Journal of Economic Issues, 36, 17-40.

Pressman, S. (2013), Fifty Major Economists, 3rd edn, London and New York: Routledge.

Rank, M. (1989), Fertility among Women on Welfare: Incidence and Determinants, American Sociological Review, 54, 296-304. 
Rathbone, E. (1917), The Remuneration of Women's Services, Economic Journal, 27, 55-68.

Rathbone, E. (1924 [1947]), The Disinherited Family, London: Allen \& Unwin.

Rathbone, E. (1940), The Case for Family Allowances, Harmondsworth, UK: Penguin.

Richardson, J.H. (1924), The Family Allowance System, Economic Journal, 34, 373-386.

Rowntree, B.S. (1901), Poverty, A Study of Town Life, London: Macmillan.

Rowntree, B.S. (1918), The Human Needs of Labour, London: Thomas Nelson.

Samuelson, P. (1948), The Simple Mathematics of Income Determination, in: Income, Employment and Public Policy: Essays in Honor of Alvin H. Hansen, New York: W.W. Norton, pp. 133-155.

Samuelson, P. (1956), Social Indifference Curves, Quarterly Journal of Economics, 70, 1-22. Sapolsky, R. (1998), Why Zebras Don't Get Ulcers, New York: W.H. Freeman.

Scott, R. and Pressman, S. (2013), Debt-Poor Kids, Journal of Poverty, 17, 356-373.

Select Committee on Labourer's Wages (1824), Report, House of Commons, Parliamentary Papers, 392, VI.401.

Smeeding, T., Buhmann, B., and Rainwater, L. (1988), Equivalence Scales, Well-Being, Inequality and Poverty: Sensitivity Estimates Across Ten Countries Using the Luxembourg Income Study (LIS) Database, Review of Income and Wealth, 34, 115-142.

Stocks, M. (1949), Eleanor Rathbone, London: Gollancz.

Toye, J. (2000), Keynes on Population, Oxford and New York: Oxford University Press.

US Census Bureau (2008), Poverty in the United States: 2007, Washington, DC: Government Printing Office.

Vadakin, J. (1968), Children, Poverty, and Family Allowances, New York: Basic Books.

Vlasto, O. (1926), Family Allowances and the Skilled Worker, Economic Journal, 36, 577-585.

Wilkinson, R. (1994), Health, Redistribution and Growth, in: A. Glyn and D. Miliband (eds), Paying for Inequality: The Economic Cost of Social Injustice, London: Rivers Oram Press, pp. 24-43.

Wilkinson, R. (1996), Unhealthy Societies: The Afflictions of Inequality, London and New York: Routledge.

Wilkinson, R. (2000), Mind the Gap, London: Weidenfeld \& Nicolson.

\section{APPENDIX}

\section{Table A1 Original data sources}

\begin{tabular}{ll}
\hline Country & Survey \\
\hline Canada & Survey of Labor and Income Dynamics, 2004 \\
Finland & Income Distribution Survey, 2004 \\
France & Household Budget Survey, 2005 \\
Germany & German Social and Economic Panel Study, 2010 \\
Luxembourg & Survey on Income and Living Conditions (SILC), 2010 \\
Norway & Income Distribution Survey, 2004 \\
Sweden & Income Distribution Survey, 2005 \\
UK & Family Resources Survey, 2010 \\
US & Current Population Survey (Annual Social \& Economics Supplement), 2010
\end{tabular}

